\title{
Theological Higher Education Leadership Challenges and Solutions Amidst the Covid 19 Pandemic
}

\author{
Ayuk Ausaji Ayuk \\ Asian Seminary of Christian Minitries, Silang, Philippines \\ Email:drayuk@gmail.com
}

\begin{abstract}
A hermeneutical study on higher education response to the crisis in education during the pandemic. It was discovered that higher educational institutions were able to handle the crisis of the time creatively and successfully as the positive points of the challenges outweigh the negative points of the situation. The negative experiences included: Poor internet connection, lack of necessary technological equipment, online education health related issues, and home distractions. Whereas the positive points are as follows: The reawakening of the online learning system, a viable alternative to the classroom, sociability, opportunity for parents to nurture their children while studying, practical and safe access to education, and the future of education online. This shows clearly that the challenge became an opportunity in disguise by creating an added means of providing an opportunity for people to have access to education. The study has made educators aware of the fact that online education is no more a dream very far away, but rather a reality at the doorstep if we are willing to take advantage of it and expand our classrooms far beyond the enclave of our educational institution's campuses.
\end{abstract}

\section{Article History: \\ Received : 6 June 2021 \\ Accepted : 9 February 2022}

Keywords:

pandemic;

education;

online;

theological;

higher education;

leadership;

solutions.

\section{Introduction}

The challenges of the times are unparallel, as a matter-of-fact humanity is challenged to the core. Almost all sectors of the human society were put to a halt because of the pandemic. How can we survive without the necessities of life? The worst part of it all, is that we cannot interact with one another freely anymore, we must stay six feet apart from one another. The spirit of working together has been quenched. Teamwork, fellowship in churches became things of the past. We must stay apart to avoid contamination at all costs. Being sick except from Covid 19 was suspended. People hardly go to the hospital because the hospitals were full of covid19 patients. And, even if you are sick of covid 19, there is no bed and room vacancy for you. The hospitals were overflowing with patients. This is the state of the world today. 
Educational Institutions have been shut down except for those institutions that are able to operate online. Thanks to technological advancement, if not we would have been totally shut down, even this conference will not have been possible. We may have been ignoring technology and having our reasons for doing so, but we can no longer afford to do so, if we do, we will be totally paralyzed. Even before now educational institutions were already having their own problems of not being able to recruit the number of students to sustain the running of the institutions. The current issue has quadrupled the myriad of challenges experienced by higher educational institutions such as low student recruitment or enrollment, lack of qualified faculty members, poor leadership, financial constraints, epistemological, metaphysical, and axiological polarity, that threatens the validity education by some sectors.

These and many other issues are confronting not only the secular and public higher educational institutions but also theological educational institution. The question is how can we get out of this thresh hole? This same question was asked many years ago by V. Raymond Edman, "Can the Christian College Survive?"1

Edman went on to say; "Spiritual decay of any Christian college starts in the trustees and administration and not in the student body". History will never cease to repeat itself. We are facing the same issue today in 2021, and the backdrop as stated by Edman is still leadership. John Maxwellis right in saying: "Everything rises and falls on leadership." Rightly so, because if the leadership does not take charge of the philosophy, vision, mission, values, and goals of the higher educational institutions who will? And, if the meaning of Christian education is not well articulated; who is to be blamed? That is why it becomes crucial for us to answer the question "What do we mean by "Christian college"? And how should it be conducted in the $21^{\text {st }}$. century?

A Christian College is "an organized educational institution of higher learning which presents the Christian theistic view of the world, of mankind, and of human culture in the light of biblical and natural revelation. It is committed to the great essentials of the Christian faith: the inspiration of the Bible, the Deity of the Lord Jesus Christ, the atoning death of the Savior, and his resurrection. And its purpose and program are distinctly Christian, as well as its administration and faculty."

This paper is an attempt to grapple with questions relating to the challenges faced by higher education institutions during the pandemic and more over give insights on how the

\footnotetext{
${ }^{1}$ Edman, V. Raymond. "Can the Christian College Survive?" Christian Today, 12 May 1958. https://www.christianitytoday.com/ct/1958/may-12/can-christian-college-survive.html, April 20, 2021.

${ }^{2}$ John Maxwell, The 21 Irrefutable Laws of Leadership. (London, UK: Pearson Education, 1998), 225.

${ }^{3}$ Edman, V. Raymond. "Can the Christian College Survive?" Christian Today.
} 
students, faculty, and leadership responded. The research investigated how some theological seminaries and higher education institutions adjusted to the situation and successfully come out of it.

Theological schools have goals, but the goals are not very clear in the sense that even the leadership is confused as indicated here by a well-meaning person. To put things in their right perspective it is important to take note of Dan Ayleshire comments when asked "What is the major issue facing mainline theological educators?" ${ }^{4}$ His answer was flabbergasting: "I think the major issue is this: What is the value of seminary-educated leadership?" He continued by saying; do seminaries really add "enough value to religious leadership that it is worth the effort, time and money?" Ruthven was said by someone who is the head of the Association of Theological Schools in North America. ${ }^{5}$ Yes, are seminaries doing their job as educators? Are the curriculums meant to answer to the needs of the church or are there academically incline?

This study dealt with the challenges of the pandemic on the educational sector and the solutions to the challenges that were faced by the educational leaders. The challenges are global as indicated in recent studies and many schools across the world were faced with the same problems as indicated here:

"In higher education institutions the landscape quickly evolved, with senior leaders initially tasked with making rapid-fire decisions, while keeping the health and safety of students, faculty, and staff foremost in their planning. In early spring 2020, academic leaders engaged in a first wave of decisions: canceling events, moving students' home, shifting instruction online, and modifying university policies and procedures." ${ }^{.6}$

These actions by schools in other parts of the world were also experienced in the Philippines. School Administrators, also experienced enrollment declines, substantial drop in undergraduate and graduate enrollment due to the inability to afford university education because of unemployment and lack of training to undertake online education. ${ }^{7}$

\footnotetext{
${ }^{4}$ Jon Mark Ruthven. "Are Pentecostal Seminaries a Good Idea?" Pneuma: The Journal of the Society for Pentecostal Studies 26, no.2 (Fall 2004): 339. https://doi.org/10.1163/157007404776111009.

${ }^{5}$ Jon Mark Ruthven. “Are Pentecostal Seminaries a Good Idea?”: 339-345.

${ }^{6}$ Sharon D. Kruse, Donald G. Hackmann, \& Lindle, Jane Clark. "Academic Leadership During a Pandemic: Department Heads Leading With a Focus on Equity.” Frontiers in Education Vol.5 Art.614641 (17 December 2020): 114. https://doi.org/10.3389/feduc.2020.614641, https://www.frontiersin.org/articles/10.3389/feduc.2020.614641/full, June 18, 2021.

${ }^{7}$ Sharon D. Kruse, Donald G. Hackmann, \& Lindle, Jane Clark. “Academic Leadership During a Pandemic: Department Heads Leading With a Focus on Equity": 1-14.
} 
It has become imperative for research to be done to find out the impact of the pandemic on educational institutions and how the leaders and students responded. The findings will help educational leaders see what can be done to make sure that educational institutions will not be taken unawares in the future, when emergencies like the pandemic occur. There has been only one dominant way of providing education, which may not always be always effective and efficient, so we need to come up with new ways of providing education to the public.

Hermeneutical research design is utilized in this study. It is an "interpretive paradigm where the central goal is to seek to interpret the world, particularly the social world, (and where) knowledge ... comprises constructions arising from the minds and bodies of knowing, conscious and feeling beings ... generated through a search for meaning, beliefs, and values, and through looking for wholes and relationships with other wholes." ${ }^{\prime 8}$ The interpretive paradigm is suitable for this study, which investigates higher education institutions and theological schools' leadership challenges and solutions amidst the Covid 19 Pandemic. The researcher will be looking at the meanings school leaders and students give to the present situation of things.

Higher education and theological schools' leadership challenges and solutions amidst the Covid19 pandemic relied on the making of meanings out of current literature and the opinions of those who took part in the research study. The hermeneutical approach is "grounded in the philosophy of idealism where the emphasis is on "embodied knowing as a determinant of social reality, (with recognition of) multiple constructed realities" Within this paradigm researchers are interested in the various ways that people understand human phenomena, acknowledging that there are many ways of viewing these phenomena. Interpretivist thinking is associated with Weber, who suggested that in the human sciences we are concerned with Verstehen or understanding of the human world. Within this approach researchers seek culturally derived and historically situated interpretations of the social lifeworld."

\footnotetext{
${ }^{8}$ Margo Paterson and Joy Higgs. "Using Hermeneutics as a Qualitative Research Approach in Professional Practice." The Qualitative Report 10, no.2 (2005): 4. https://doi.org/10.46743/2160-3715/2005.1853; K. Bockmuehlt. Evangelicals and Social Ethics: A Commentary on Articles 5 of the Lausanne Covenant, U. S. Catholic Bishops, Economic Justice for All. (Downers Grove, IL: InterVarity, 1979).

${ }^{9}$ Margo Paterson and Joy Higgs. "Using Hermeneutics as a Qualitative Research Approach in Professional Practice": 5; B. J. Coggle and J. P. Byrnes. Christian Social Ethics: A Methodist Approach. (London: Epworth, 1956); Esther O. Ayandokun. "Theological Education and Leadership Integrity: A Response to Leadership Challenges in Africa." InSights Journal 6, No.2 (2021): 60-71. https://insightsjournal.org/theological-education-and-leadership-integrity-aresponse-to-leadership-challenges-in-africa.
} 
Hermeneutics was chosen as the most appropriate research design because the research goal was to interpret how students and leaders perceive the pandemic and its impact on educational institutions and its leadership. According to Paterson \& Higgs, "Hermeneutics is the theory and practice of interpretation." ${ }^{\text {"I }}$ It belongs to a family of interpretive approaches to science rather than a single, wholly unified scientific philosophy. It originated in the 17th century as an approach for interpreting biblical texts. Hermeneutics eventually expanded to include the study of human behavior. ${ }^{11}$

The word hermeneutics is derived from the Greek verb hermeneuein, which means 'to interpret' with the noun hermeneia, which means 'interpretation". The different forms of the word suggest the process of bringing a thing or situation from unintelligibility to understanding. The word 'hermeneutics implies the process of making something understandable. ${ }^{12}$ It is exactly what will be done in this study, which is an attempt to bring into understanding the nature of the pandemic on educational institutions and the leadership response to it. The interpretive paradigm is the most appropriate for this study because it involves the giving of meaning to the pandemic situation and the appropriate steps that are taken to address the situation.

Hermeneutics is chosen as the methodology for this study because it involves the meanings educational institutions give to the pandemics. Theology is said to have been the first to utilize hermeneutics in the understanding of scriptural text. The work of the theologian is to make something that is unfamiliar, distant, and obscure in meaning into something intelligible. Theologians have the responsibility of explaining the scripture. ${ }^{13}$ In this case, the study utilized hermeneutics to unravel the responses to the pandemic and why? This will help put the research

\footnotetext{
${ }^{10}$ Margo Paterson and Joy Higgs. "Using Hermeneutics as a Qualitative Research Approach in Professional Practice": 5 .

${ }^{11}$ Michael E. Patterson and Daniel R. Williams. "Collecting and analyzing qualitative data: Hermeneutic principles, methods and case examples." Advances in Tourism Applications Series, Volume 9. (Champaign, IL: Sagamore Publishing, Inc., 2004).

${ }^{12}$ K. H. Chang and Stephen Horrocks . "Is there a place for ontological hermeneutics in mental-health nursing research? A review of a hermeneutic study." International Journal of Nursing Practice 14, iss.5 (2008): 383-390. https://doi.org/10.11l1/j.1440-172X.2008.00702.x; J. Grondin. Introduction to Philosophical Hermeneutics. Yale Studies in Hermeneutics edition. John Cleary and Pádraig Hogan (ed.), (New Haven, Connecticut: Yale University Press, 1997).

${ }^{13}$ Chak Kwan Chan. "Safeguarding the Dignity of My Poor Brothers and Sisters: A Reflection of Hong Kong Christian Churches' Financial Assistance.” Journal of Asian Mission 4, no.2 (2002): 267-286 ; Paul Ricoeur. From Text to Action: Essays in Hermeneutics, II (Studies in Phenomenology and Existential Philosophy). K. Blarney and J.B. Thompson (transl.). (London: The Athlone Press, Edition 13, 2007); M. El Gedawy. Hermeneutics as a Research Method. Fall 2004 Para. 5. Retrieved May 15, 2012, from the Website: http://www.people.iup.edu/rhml/Hermeneutics.htm.
} 
in the right perspective, since it is an attempt to come up with a deeper understanding of the responses and solutions to the pandemic.

It is an analytical and critical discourse between two individuals sometimes with different worldviews and in different times. One enters this dialogue with his/her own preconceived notion of things which can be said to be prejudice (a-priori nature of knowledge). The interpreter or exegete is subjective in the sense that he/she is a part of a tradition that is naturally brought into the dialogue. It is based on this prejudice that the initial steps of interpretation are taken. ${ }^{14}$

The question is what is education and how should it be done and why? Given the present situation that educational institutions are in. A hermeneutical research methodology stands out as the most appropriate research method to be utilized in this study. Schleiermacher is said to have been the first person to use the term hermeneutics. He made it a universal discipline from its obscure use in the interpretation of scripture, to being applied equally to all subjects' areas. ${ }^{15}$ The prerequisite for interpretation is a good knowledge of the historical context and the author's psychology. "Interpretation for Schleiermacher always has two sides: one linguistic, the other psychological, studied closely within a historical context. Linguistic interpretation is mainly concerned with what is common or shared in a language, and psychological interpretation mainly with what is distinctive to a particular author." ${ }^{16}$

According to Hunter "Hermeneutics involved an attempt, through analysis of text, to recreate as much as possible, the original intention of the author without being limited by the lens of historical or religious tradition, nor the lens of contemporary culture". ${ }^{17}$ The present study took into consideration the elements of hermeneutics in giving meaning to the present situation that is studied. In hermeneutics the researcher engages oneself with the rigor of finding the meaning of a text by trying to, understand, exegete and explore. This process involves taking a

${ }^{14}$ Gadamer, in Shusterman 1989, N.G. Noorderhaven. "Positivist, hermeneutical and postmodem positions in the comparative management debate." in M. Maurice and A. Sorge (eds.). Embedding Organizations: Societal Analysis of Actors, Organizations and Socio-Economic Context. (Amsterdam: John Benjamins, 2000), 117-137.

${ }^{15}$ K. H. Chang and Stephen Horrocks. "Is there a place for ontological hermeneutics in mental-health nursing research? A review of a hermeneutic study": 8-9.

${ }^{16}$ K. H. Chang and Stephen Horrocks. "Is there a place for ontological hermeneutics in mental-health nursing research? A review of a hermeneutic study": 9; J. Grondin. Introduction to Philosophical Hermeneutics. Yale Studies in Hermeneutics edition.

${ }^{17}$ Lisa Renning. "Hermeneutics in Qualitative Research.” EDUC 867. https://www.sfu.ca/educ867/htm/hermenteutics.htm. Retrieved April 3, 2012. 
critical analytical look into the historical, geographical, and cultural context in which the text was written. It is a deductive process. ${ }^{18}$

Generally, hermeneutics as a research methodology involves the generalization of a concept taken from a text in the Bible, literary piece, or history. The text is given a coherent meaning or sign, which makes it a form of reading. ${ }^{19}$ The meanings given to the text are said to be the "intentions or beliefs of their 'authors'. ${ }^{20}$ It is in this regard that hermeneutics was chosen as the research methodology for this study, that deals with the perceptions and responses of respondents to the pandemic in the educational sector.

\section{Finding And Discussion}

The participants of the study were school leaders, graduate students in a seminary and university. Some of the graduate students are handling leadership positions in educational institutions. They were able to share their challenges, strategies, and experiences in handling the situation during the pandemic. Most importantly participants shared their experiences in online synchronous classes. The experiences were challenging and yet rewarding in some sense and as such are classified as negative and positive. The negative categories are the difficult experiences, and the positive categories are the responses to the problems that were encountered.

It was not smooth at the beginning of the pandemic because everyone was adjusting to the new normal of conducting classes online. Both teachers and students were learning to use the online platforms available to conduct classes. The use of face book messenger as a platform for conducting online classes was very challenging, but that is where most of the schools started, and it served its purpose for the time being. ${ }^{2 l}$ The participants involved in this study have moved from this basic platform to more sophisticated platforms like Google classroom, MSTeams, and Zoom.

\footnotetext{
${ }^{18}$ Byrne, 2003.
}

${ }^{19}$ Paul Ricoeur. The Conflict of Interpretations: Essays in Hermeneutics (Studies in Phenomenology and Existential Philosophy). Don Ihde (ed.). (Evanston, Illinois: Northwestern University Press, Edition 13, 2007); Thompson 1993.

${ }^{20}$ N.G. Noorderhaven. "Positivist, hermeneutical and postmodem positions in the comparative management debate."

${ }^{21}$ H.K. Klein and Michael D. Meyers. "A Set of Principles for Conducting and Evaluating Interpretive Field Studies in Information Systems.” MIS Quarterly, 23 (1999): 67-94. https://doi.org/10.2307/249410. 


\section{Negative Experiences}

The negative experiences point to the fact that there were difficult moments during the transition from offline to online. It was a time of uncertainty, confusion, and disbelief as to what is happening or will happen because of the situation of things, which is the pandemic. It was a trying time, so to say. There was a lot of negation from all sectors. One of the participants has this to say about the situation:

"The decision to resume courses in the face of the epidemic has been the topic of many discussions. Many people are advocating for the education system to skip current school year to ensure that no kid is left behind, and many parents are still ready to experiment with how remote learning will function in the future." ${ }^{22}$

This was the voice of the confusion that was ongoing at the beginning of the pandemic.

This confusion led to one of the biggest challenges educational institutions faced at the beginning of the pandemic, which is: How are we going to deal with the suspension of classes by the government due to the spread of COVID 19? Many schools were faced with this challenge. Where do we go from here? This was a very critical question by leaders of educational institutions and especially leaders who did not have an on-going online program.

The second challenge is finding and hiring an IT personnel to manage the online program. The next question is what online or social media platform is the most applicable for our current need? The good thing about the Philippines Educational System is that the commission on higher education was able to intervene and provide flexible alternatives and solutions to the problem. ${ }^{23}$ This gave educational institutions the direction on what to do about the situation.

The third challenge is: Do the students have the necessary skills and equipment like cellphones, computers, and iPad or Tablet to use for the online classes. You will be surprised to know that even some faculty members do not have these necessary gadgets to use. Financial, constraints led some schools to close, because money is needed to hire IT experts, buy equipment, and train both students and faculty on how to use technology.

The set back of the pandemic is demonstrated by one of the participants who said, "The effects of the pandemic can mostly be seen in private schools as financial resources were saturated because of the significant drop in the enrollment, as well as the minimal government

\footnotetext{
${ }^{22}$ Interview on February 2019 to April 2021.

${ }^{23}$ Queenie Pearl Villalon Tomaro. "ICT integration in the educational system of Philippines." Journal of Governance and Public Policy 5, no.3 (2018): 259-282. https://doi.org/10.18196/jgpp.5399.
} 
financial support. Incentives for students can also be given to be used for acquiring technology, internet connection, and tutorial services." In general, these were some of the negative setbacks that were experienced during the initial stage of the pandemic, but there other more categorical setbacks that will be discussed below:

\section{Poor Internet Connection}

Without internet connection it will be impossible to carry on the online classes. Internet connectivity is the priority in online education, you may have all the gadgets to use for online education, but if you do not have internet access you will not be able to have access to online education. So, students with poor internet connection are from time to time disconnected from the online session hence student's concentration is affected during synchronous sessions.

This was the experience of some students who could not attend sessions because they were disconnected due to the poor internet connection or lack of money to pay for the internet services. One of the students stated:

"For the disadvantages of using synchronous sessions first is the stability of the internet connection at home, having poor signal could interrupt anytime and cause loss of attention, second requesting for on camera while having classes will not be possible because of limited data, but if I could hear clearly the discussion of the professor it would be enough for me." ${ }^{24}$

The student was stating the difficulties students experience when they have poor internet connection. They experience interruption of classes, which affects their concentration and moreover, they are not able to use all the functionalities of the platform they are using for the online sessions, like video and camera, so they can see other participants and the facilitator.

\section{Lack Of The Necessary Equipments}

Aside from poor internet connection students are also unable to buy the necessary gadgets to be used for the online class sessions. This was clearly stated by one of the participants:

"Remote learning presents several difficulties for many Filipino students, and this is not a secret. All Filipino parents, no matter how much they would want to, are unable to provide their children with a laptop, a computer, or even a tablet or a mobile phone, let

\footnotetext{
${ }^{24}$ Interview on February 2019 to April 2021.
} 
alone an internet connection, despite their best efforts. Many people lost their jobs because of the epidemic."25

It was further reiterated by another student who said:

"More students experienced many problems and challenges as they pursue education in the new normal. Those who are poor and have no gadgets to be utilized in their distance learning were further challenged. Yes, modular distance learning is the answer, but the communication was still problematic to both teachers and students who has no access to one another." ${ }^{26}$

This experience is not limited to the Philippines alone as stated below:

"Some students without reliable internet access and/or technology struggle to participate in digital learning; this gap is seen across countries and between income brackets within countries. For example, whilst $95 \%$ of students in Switzerland, Norway, and Austria have a computer to use for their schoolwork, only 34\% in Indonesia do, according to OECD data. ${ }^{27}$

This is a global problem that should be dealt with accordingly, as we prepare to enter another phase in the educational sector. We should not only be concern with building schools but with providing the necessary equipment and facilities needed to undertake a more functional educational system. The fact remains that the computer industry will have a steady business for a very long time, since every student will be required to have a laptop and other necessary gadget. Well, it is not like educational institutions are making the computer industry viable, but rather that computers are making education accessible to all people.

\section{Online Education Health Related Issues}

While technology remains the most viable option during the pandemic, it is also true that the use of technology for a prolong period has its side effect. The health issues associated with the use of technology has something to do with the eyes, ears, and headaches. These issues may lead to mental health issues. That is why faculty and students are required to have self-care weeks to destress themselves from the strain of facing the computer for a long period of time.

According to the Department of Health in the Philippines it is possible for students to experience physical and mental health issues as they adjust to the shift from the traditional to online teaching and learning. "With online classes, there could be increasing feelings of isolation

\footnotetext{
${ }^{25}$ Interview on February 2019 to April 2021.

${ }^{26}$ Interview on February 2019 to April 2021.

${ }^{27}$ Gonzalo Fuentes. "The COVID-19 pandemic has changed education forever. This is how." World Economic Forum, 229 April 2020. https:/www.weforum.org/agenda/2020/04/coronavirus-education-global-covidl9-onlinedigital-learning/ Accessed June 18, 2021.
} 
due to lack of face-to-face interaction," said the DOH. "Students may experience health concerns related to increased screen time, such as fatigue, headache, lack of motivation, avoidance/procrastination, among others, ${ }^{128}$

It was advised that students take care of themselves by establishing

"a routine, wherein there is an academic and personal life balance, which includes being physically active, eating, and sleeping. "(It would be good to) take breaks in between classes and having time away from the computer,". The health department also said that mental health problems for children may be avoided by encouraging them to speak out loud their thoughts and feelings to others. "Practice self-care, self-compassion, and selfawareness of their thoughts and feelings. ${ }^{.29}$

This is a minor problem that can be handled by taking the advice given by the Department of Health in the Philippines. However, the issue should not be taken for granted, if we want to avoid mental health issues, that can be disastrous. One of the participants has this to say: "Another worst-case scenario that a school manager should prepare is that as expected, student's' drive for learning will be exacerbated due to their mental health's condition during the Pandemic. Because of this, it is reasonable for a school manager to consider stress debriefing during class sessions and at the same time just enough school load so it will be easier for them to cope up" Recognizing these facts will be very crucial for classroom management.

\section{Home Distractions}

Learning from home has its own distractions like having visitors, doing household chores. Most pastors have no clear schedule for guests to visit them at home, so it is not surprising that visitors can just show up on their doors and they will have nothing to do but welcome them into the house and that will be the disruption of synchronous sessions, or the time scheduled to do asynchronous assignments. Aside from the disturbance of unwanted visitors, students can sometimes be overwhelmed by household chores. Being at home can sometimes, mean being concern about what needs to be done at home, which would have not bothered the student if he/she were in school attending classes.

\footnotetext{
${ }^{28}$ HDT. "DOH warns of possible health problems from online classes." SunStar, (Manila, 5 September 2020). https://www.sunstar.com.ph/article/1869290/Manila/Local-News/DOH-warns-of-possible-healthproblems-from-online-classes June 28, 2021.

${ }^{29}$ HDT. "DOH warns of possible health problems from online classes."
} 
One of the students pointed this out: "There is nothing I can do when visitors show up in the house and moreover, I am bothered by the household chores that keep distracting me from my studies at home" This challenge can be dealt with by the students by scheduling time for the different activities that should be done at home. Time management should become an important value to be taught in the schools during students' orientations.

\section{Positive Experiences}

The challenges faced by school leaders, faculty, and students during the period of pandemic led to new insights on how education can be done. The new insights brought about by the challenges are termed as positive experiences. The Challenges provided the opportunity for the educational institutions to see new ways in which education can be offered. This has become a source of help for educational institutions to help different categories of students to be engaged in learning. Many schools were only operating on a face-to-face platform, but with the emergence of the pandemic schools have come up with alternative ways of conducting classes online. One of the schools sent this message out to the faculty:

"In accordance with the Commission on Higher Education (CHED) guidelines on tertiary education during community quarantine periods classes will be offered fully online in AY 2020-2021. The guideline stipulates that the first semester will be fully online. Thereafter, if the situation improves, blended online and face-to-face classes and fully on-campus face-to-face classes can be offered." ${ }^{30}$

This was impossible for any institution to do without Level 4 Accreditation status, but the department of education was now allowing all schools to operate online programs even without the level 4 Accreditation. This is a positive experience for the schools. One of the participants has this say:

"Truly, the Covid-19 pandemic has struck the world by surprise and caused so many changes in terms of the global economic flow including businesses, trade, tourism, and even education. Children and adolescents became so immersed in the new ways of learning and attending classes which created huge impacts in every aspect of their lives. However, this pandemic made us realize that utilizing technology can be an effective tool to make the classroom more accessible particularly for students with disabilities and those who are experiencing difficulties coming to the physical school."31

\footnotetext{
${ }^{30}$ Interview on February 2019 to April 2021.

${ }^{31}$ Interview on February 2019 to April 2021.
} 
So, we can say with gusto that the pandemic has helped educational leaders to see things differently and for the good of all. This has led school leaders to an awakening that should be felt by those who are still struggling with the fact that education can be offered online and there is nothing wrong with that. This has brought about the acceptance of online or distance education which has been kind of skeptical in the minds of many educators.

\section{The Awakening Of The Online Learning System}

The answer to the question where do we start now? Started with many schools being awakened from the deep slumber of their online programs. The online programs were already established in some universities and seminaries, but they were underused by the faculty members, even though the administration was encouraging and motivating the faculty members to undertake blended teaching and learning. This means fifty percent of the face-to-face teaching was to be blended with fifty percent online. This should have been a good start, but it was reluctantly accepted, until everyone was forced by the pandemic to be engaged in online teaching and learning one hundred percent. ${ }^{32}$ Thanks to School Administrators who have started preparing a head of time to make education accessible to all students whether in the classroom or online. This preparation made it possible for some schools to easily adjust to the online program during the pandemic.

Apart from schools with already established online learning systems reawakening them, online learning platforms like MSTeams, Google Classroom and Zoom were put into usage by many schools. These Social Media platforms may not be stable but have been very useful to educational institutions with online programs. They are really cost effective. It will cost an educational institution a fortune to establish its own online program, but it costs some schools nothing to use google classroom. According to Blackmon et.al., "Many studies have clearly shown that online and offline instructions often have similar or slightly more positive outcomes in the primary areas of cognitive gain." This fact has been proven right by the current situation of things in many higher education institutions. ${ }^{33}$

\footnotetext{
${ }^{32}$ M. Forsgren. Some Critical Notes On Learning In The Uppsala Internationalization Process Model. Occasional Paper 2000/2. (Uppsala, Sweden: Företagsekonomiska Institutionen, Uppsala University, 2000), 1-24.

${ }^{33}$ Stephanie J. Blackmon and Claire Major. "STUDENT EXPERIENCES IN ONLINE COURSES: A Qualitative Research Synthesis.” The Quarterly Review of Distance Education 13, no.2 (2012): 77-85. https://www.cu.edu/doc/student-experiences-online-classesqual-study.pdf.
} 


\section{A Viable Alternative To The Classroom}

The classroom has always been seen as the most effective and efficient means of teaching and learning, but that is about to change especially for graduate students. Many of the graduate students see online learning as a very viable option to classroom learning as pointed out here: "The online classes are same with face to face." $" 34$ That comment has a lot of implications. It means there is no difference between online teaching and learning in the classroom, which means effective learning can take place online, then why bother to travel a long distance just to attend a class that you can stay at home and attend? Besides, the student will not have to spend for transportation and food, which means online education is cost effective. One of the students indicated that; "It has helped in taking away the need to travel to school thereby saving time and money used for travelling to school." These are some of the advantages of online learning, which makes it a viable option to the classroom.

\section{Sociability}

Online education is generally seen as detached and distant, which to some will mean there will be lack of communication, but that is not the way it has been experienced by many graduate students. As a matter of fact, one of the students pointed out: "It encourages discussion and interaction because reading assignments are given a head of time". ${ }^{35}$ This is incredible, but it is true because many students come to class prepared. The online synchronous facilitator prepares and uploads the lesson before the synchronous meeting time and so the students get to read the lesson before attending the session, which makes it possible for the students to engage in discussion during the synchronous session. Discussion and interaction are very important in teaching and learning, but if the students are not prepared to discuss and interact it will be impossible for the students to discuss with their teacher and fellow students. So, asynchronous activities and assignments are very important. The reading of the materials is made possible because the students will not need to travel. The time spent travelling will be used to read.

\footnotetext{
${ }^{34}$ Montgomery Van Wart, Anna Ni, Pamela Medina, Jesus Canelon, Melika Kordrostami, Jing Zhang, and Yu Liu. "Integrating students' perspectives about online learning: a hierarchy of factors." International Journal of Educational Technology in Higher Education 17, no.53 (2020). https://doi.org/10.1186/s41239-020-00229-8.

${ }^{35}$ Interview on February 2019 to April 2021.
} 


\section{Provides Opportunity For Parents To Take Care Of The Family}

Most at times the reason those with families, especially the mothers quit schooling is because they have children to take care of at home. Parents who do not have a trusted person to take care of their children at home will rather give up schooling than take the risk of entrusting their child to someone else. So, mothers can say that the online classes have "Helped in providing time for me to take care of the family as a mother." Parents and mothers can now have access to education without having to leave the comfort of their homes. The pandemic has therefore made it possible for educators to see another way to offer education to all who are interested in going to school. Blackmon, Stephanie J. and Major, Claire also found out in their study that "Interestingly, the most common potential barrier to educational attainment that students mentioned was family, and that also was the factor that made them most grateful for the opportunity and the experience. ${ }^{36}$

\section{Practical And Safe Access To Education}

The online platform is said to be Practical and safe as indicated by some of the participants; "It is very practical and safe while enjoying learning at home without hassle." We can understand the implication of this statement, which implies students will be safe from contracting the virus, and sometimes safe from the dangers of traveling to school or getting shot by a classmate if they were in the United States of America. But safety goes beyond physical harm as indicated by Jocelyn Wishart, "breaches of Internet Safety reported by schools in the main study were most likely to be pupils accidentally accessing inappropriate material. The LEA advisors also reported accidental access of inappropriate material as the most frequent breach of Internet Safety heard of by them with 5 of the 18 hearing about it more than once a term followed closely by deliberate access. ${ }^{37}$ So, while we may not worry about physical harm, we should be worried about online safety.

Yong Chen \& We He have also given us another idea of safety when they said: "In online learning, security means that "learning resources are available and unimpaired to all authorized

\footnotetext{
${ }^{36}$ Stephanie J. Blackmon and Claire Major. "STUDENT EXPERIENCES IN ONLINE COURSES: A Qualitative Research Synthesis": 80.

${ }^{37}$ Jocelyn Wishart, "Internet Safety in Emerging Educational Contexts." Computers \& Education 43, iss.1-2 (2004): 198. https://doi.org/10.1016/j.compedu.2003.12.013.
} 
users when they are needed." ${ }^{38}$ Since online learning takes place via the Internet, every element in an online learning system can be a potential target of hacking or attacks. This may lead to unauthorized modification and/or destruction of educational assets. ${ }^{39}$ Online learning must consider the inherent security risks on the Internet, such as identity theft, impersonation, and inadequate authentication. ${ }^{40}$ Online learning systems have attracted the attention of cybercriminals who thrive on their ability to hack into such systems. The risk is great; as the functionalities and features of online learning systems become more complex, online learning is increasingly exposed to security threats." ${ }^{41}$ There are therefore many ways to look at safety and security when it comes to online education. However, safety in this study has to do with conduciveness and absence of physical harm.

\section{The Future Of Education According To Educational Leaders}

The future of education will be dependent on technology as stated by one of the participants. "But then, technology would play a vital role in crafting the schools of the future. If the government can aid all citizens to have access to technology, then education would be better across the world. Massive Online Open courses are already available. I had my certificate from University of Berkeley in California, and I got it from the comforts of my own home." It is even believed that technology is an effective tool in making education possible and accessible. This was clearly stated by one of the leaders in education.

"This pandemic made us realize that utilizing technology can be an effective tool to make the classroom more accessible particularly for students with disabilities and those who are experiencing difficulties coming to the physical school. The Department of Education, together with the other private school sectors, embraced mainly the technology to continue education. This "school by screen" technique paved the way for an easy-access teaching and learning mode for both students and teachers."

The future of education will be more of a strong emphasis on blended learning, which will include both online and classroom teaching and learning. Moreover, curriculums will need

\footnotetext{
${ }^{38}$ Adams \& Blandford, 2003 in Yong Chen \& Wu He. "Security Risks and Protection in Online Learning: A Survey." The International Review of Research in Open and Distance Learning 14, no.5 (2013): 108-127. https://www.learntechlib.org/p/171371.

${ }^{39}$ Zuev, 2012 in Yong Chen \& Wu He. "Security Risks and Protection in Online Learning: A Survey."

${ }^{40}$ Ayodele, Shoniregun, \& Akmayeva, 2011 in Yong Chen \& Wu He. "Security Risks and Protection in Online Learning: A Survey."

${ }^{41}$ Alwi \& Fan, 2010 in Yong Chen \& Wu He. "Security Risks and Protection in Online Learning: A Survey": $109-110$.
} 
to be improved, especially in learning experiences. The revision of curriculums for higher education will include online learning as the learning experiences, as indicated below:

"A curriculum that will promote blended learning and will promote individualized approach to teaching and learning. Both DepEd and CHED should develop regulations about blended and distance education and continue to reach for existing schools to give support to learning continuity and expand digitalization in the educational sector. It is important that we don't only recover from the pandemic, but we can be able to use our experiences to become better and prepared for future crises. ${ }^{42}$

Another participant reiterated that:

"This will also require all higher educational institutions to revise and recalibrate their curriculum in teaching students of the "teaching course" to be taught of the "new" ways of teaching in the new normal. Schools must also be improved in term of the new demands in education. Apart from the traditional classrooms and school facilities, administrators must also pay attention on the procurement of gadgets, equipment, and facilities that could be used by teachers in the delivery of education." ${ }^{43}$

A participant paraphrased what the Commission on Higher Education Chairman said by stating: "CHED Chairman de Vera's stated that tertiary education would need to embrace flexible learning. He emphasized that there will be no going back, where flexible learning will be a new norm." In essence the Chairman is indicating that flexible learning has come to stay with the educational system, because schools must now have two options, which are the classroom and online education.

Classes will no longer be held in the classroom alone even when things are back to normal because online education is a viable option that must become part of every educational system whether it has a level 4 accreditation or not. It has always been the policy of the Commission on Higher Education to require schools to attain the Level 4 Accreditation to qualify to offer distance or online education. That policy may soon be changed since many schools have been able to perform well in online education during the pandemic.

According to Ferguson:

"As schools adopt online education in record numbers or must move entirely online during emergencies, we feel the tension of embracing this delivery method without getting our questions answered, convictions sorted, or hearts engaged in the vital work that we do. Although some educators readily see the opportunity to reach a greater

\footnotetext{
${ }^{42}$ Interview on February 2019 to April 2021.

${ }^{43}$ Interview on February 2019 to April 2021.
} 
number of students with the gospel through Christian online education, others wonder if it can achieve our objective." ${ }^{44}$

In many ways online education will surely help in fostering the accessibility of education to those who would have thought that it is impossible to have access to a good quality of education due to distance away from qualified teachers and library resources. In line with this mind set, an appropriate philosophy of education needs to be developed to suit the situation of the times.

Unless the philosophy of education is changed, and principles of educational practice are taken seriously seminaries will continue lose their place as the formators of future church leaders. The hidden curriculum plays the most important part in theological education.

\section{Conclusion}

The shift from the traditional mood of education to online education or distance learning has its challenges and setbacks, but overall, the positive points outweigh the negative points. The following setbacks were experienced by the students and educational leaders or managers: Poor Internet Connections, Lack of the necessary technological equipment, Online Education health related issues and home distractions. While the positive points were as follows; The reawakening of the online learning system, A Viable alternative to the traditional mood of learning, Sociability, Opportunity for parents to take care of their children and at the same time study, Practical and Safe Access to education and the future of education.

The strong points clearly outweigh the weak points and as such we can say that the pandemic has opened and reawaken an alternative way of offering education and making it accessible to many. There has always been distance education and online education, but right now is fully embraced by both students and educational leaders.

Technology and social media applications have been one of the greatest helps during this pandemic. There is a need for every educational institution to invest in technology because technology will be needed to facilitate education and make it accessible to all people. It may be expensive, but the need will by far outweigh the cost. The world is changing very fast due to human actions. There should be a corresponding change in the way we do things. There is

\footnotetext{
${ }^{44}$ Kristen Ferguson, Excellence in Online Education: Creating a Christian Community on Mission. MLA 8th Edition, (Nashville, Tennessee: B\&\&H Academic, 2020), 2.
} 
nothing that can substitute change but change itself. We are in the period of knowledge explosion, and all we need to do is manage the knowledge that is there for grasp by any person who wants it.

The library is no more very far from home with the Internet full of resources to tap from. The alternative for classroom will be home, church buildings and most probably offices in both urban and rural areas. This is the new normal for all of us. This study is a humble attempt to see how educational leaders managed change in some schools in Cavite, Philippines.

The need for distance education and online education has been very slow in coming. The traditional institutions will still operate as the main source for the materials of distance and online education. However, the distance and online education program should be strengthened because this is the way forward. The government and parents are still crying for the traditional way of education, but we have reached the stage that online education should be seen as a viable option to the traditional way of doing education. It is even better to be in the work setting while studying instead of staying away from the real-life situation. Schools should be encouraged to develop learning materials for students who cannot be in the school setting.

Graduate studies learning modules should also be prepared for the distance or online education program. The classroom is not the only place education can take place. That is a very traditional way of thinking about education. Education can take place anywhere as long as knowledge is gained, whether through reading or teachers input. Theological schools should begin to get ready for the future. Theological education is going to change its face in the very near future. ${ }^{45}$ The future is in homes, small groups in churches and offices.

Most of the time the curriculums are not implemented because the teachers are not well informed of what is expected of them in a particular course. They teach what they like from an academic point of view not sometimes what the curriculum expects of them. And so, the curriculum is not implemented. A well-planned educational program can make theological education worthwhile in the 2lst century. The planning must involve churches who will be having their church workers and pastors trained in the institutions. Without formal training in

\footnotetext{
${ }^{45}$ Benjamin Sun. "Assemblies of God Theological Education in Asia Pacific: A Reflection." Asian Journal of Pentecostal Studies 3, no.2 (2000): 227-251. https://www.academia.edu/64155583/Benjamin_Sun_Assemblies_of_God_Theological_Education_in_Asia_Pacific_A_ Reflection_pp_227_251.
} 
the seminaries, it would be hard to find pastors that can handle the kind of churches that would be emerging in the 21 st century. ${ }^{46}$

Those interested in studying in higher educational institutions no longer need to leave their homes to study, they can study right where they are, in the comfort of their homes. The hesitancy of sending students to school due to lack of finances will no longer be there because the housing and feeding cost will no longer be part of the expenses, due to online education. There are many churches, that would rather train their pastors than send them to bible school or seminary. They would rather invite a seminary professor to come and train their church workers than send them to the bible school. This gap will be bridge by online education. Online education has come to stay. We should embrace it wholeheartedly.

\section{References}

Ayandokun, Esther O. "Theological Education and Leadership Integrity: A Response to Leadership Challenges in Africa." InSights Journal 6, No.2 (2021): 60-71. https://insightsjournal.org/theological-education-and-leadership-integrity-a-responseto-leadership-challenges-in-africa.

Blackmon, Stephanie J. and Claire Major. "STUDENT EXPERIENCES IN ONLINE COURSES:

A Qualitative Research Synthesis." The Quarterly Review of Distance Education 13, no.2 (2012): 77-85. https://www.cu.edu/doc/student-experiences-online-classesqual-study.pdf.

Bockmuehlt, K. Evangelicals and Social Ethics: A Commentary on Articles 5 of the Lausanne Covenant, U. S. Catholic Bishops, Economic Justice for All. Downers Grove, IL: InterVarity, 1979.

Chan, Chak Kwan. "Safeguarding the Dignity of My Poor Brothers and Sisters: A Reflection of Hong Kong Christian Churches' Financial Assistance." Journal of Asian Mission 4, no.2 (2002): 267-286.

Chang, K. H. and Stephen Horrocks . "Is there a place for ontological hermeneutics in mentalhealth nursing research? A review of a hermeneutic study." International Journal of Nursing Practice 14, iss.5 (2008): 383-390. https://doi.org/10.1111/j.1440-172X.2008.00702.x.

\footnotetext{
${ }^{46}$ Rick Warren. The Purpose Driven Church. (Manila: OMF Literature Inc., 1998).
} 
Chen, Yong \& He, Wu. "Security Risks and Protection in Online Learning: A Survey." The International Review of Research in Open and Distance Learning 14, no.5 (2013): 108-127. https://www.learntechlib.org/p/171371.

Coggle, B. J. and J. P. Byrnes. Christian Social Ethics: A Methodist Approach. London: Epworth, 1956. Noorderhaven, N.G. "Positivist, hermeneutical and postmodem positions in the comparative management debate." in M. Maurice and A. Sorge (eds.). Embedding Organizations: Societal Analysis of Actors, Organizations and Socio-Economic Context. Amsterdam: John Benjamins, 2000, 117-137.

El Gedawy, M. Hermeneutics as a Research Method. Fall 2004 Para. 5. Retrieved May 15, 2012, from the Website: http://www.people.iup.edu/rhml/Hermeneutics.htm.

Ferguson, Kristen A. Excellence in Online Education: Creating a Christian Community on Mission. MLA 8th Edition B\&H Academic, Nashville, Tennessee, 2020.

Forsgren, M. Some Critical Notes On Learning In The Uppsala Internationalization Process Model. Occasional Paper 2000/2. Uppsala, Sweden: Företagsekonomiska Institutionen, Uppsala University, 2000, 1-24. https:/ideas.repec.org/p/hhb/uufewp/0002.html. March 18, 2021. Fuentes, Gonzalo. “The COVID-19 pandemic has changed education forever. This is how.” World Economic Forum, April 29, 2020. https:/www.weforum.org/agenda/2020/04/coronaviruseducation-global-covid19-online-digital-learning. Accesed March 18, 2021.

Grondin, J. Introduction to Philosophical Hermeneutics. Yale Studies in Hermeneutics edition. John Cleary and Pádraig Hogan (ed.), New Haven, Connecticut: Yale University Press, 1997.

Klein, H.K. and Michael D. Meyers. "A Set of Principles for Conducting and Evaluating Interpretive Field Studies in Information Systems." MIS Quarterly, 23 (1999): 67-94. https://doi.org/10.2307/249410.

Kruse, Sharon D., Donald G. Hackmann, and Jane Clark Lindle. "Academic Leadership During a Pandemic: Department Heads Leading With a Focus on Equity." Frontiers in Education 5 (17 December 2020): 614641. https://doi.org/10.3389/feduc.2020.614641.

Maxwell, John. The 21 Irrefutable Laws of Leadership. London, UK: Pearson Education, 1998.

Neisser, U., G. Boodoo, T. J. Bouchard, Jr., A. W. Boykin, N. Brody, Ceci, S. J., D. F. Halpern, J. C. Loehlin, R. Perloff, R. J. Sternberg, and S. Urbina. "Intelligence: Knowns and unknowns. “ 
American Psychologist 5l, no.2 (1996): 77-101. https://doi.apa.org/doi/10.1037/0003066X.51.2.77.

Noorderhaven, N.G. "Positivist, hermeneutical and postmodern positions in the comparative management debate." in M. Maurice and A. Sorge (eds.). Embedding Organizations. Amsterdam: John Benjamin, 2000a, 117-137.

Noorderhaven, N.G. Hermeneutic Methodology and International Management Research. Occasional Paper 2000/2. Uppsala, Sweden: Uppsala University, 2000b.

Paterson, Margo and Joy Higgs. "Using Hermeneutics as a Qualitative Research Approach in Professional Practice." The Qualitative Report 10, no.2 (2005): 339-357. https://doi.org/10.46743/2160-3715/2005.1853.

Patterson, Michael E. and Daniel R. Williams. "Collecting and analyzing qualitative data: Hermeneutic principles, methods and case examples." Advances in Tourism Applications Series, Volume 9. Champaign, IL: Sagamore Publishing, Inc., 2002.

Renning, Lisa. "Hermeneutics in Qualitative Research.” EDUC 867. https://www.sfu.ca/educ867/htm/hermenteutics.htm. Retrieved April 3, 2012.

Ricoeur, Paul. The Conflict of Interpretations: Essays in Hermeneutics (Studies in Phenomenology and Existential Philosophy). Don Ihde (ed.). Evanston, Illinois: Northwestern University Press, Edition 13, 2007.

. From Text to Action: Essays in Hermeneutics, II (Studies in Phenomenology and Existential Philosophy). K. Blarney and J.B. Thompson (transl.). London: The Athlone Press, Edition $13,2007$.

Ruthven, Jon Mark. “Are Pentecostal Seminaries a Good Idea?" Pneuma: The Journal of the Society for Pentecostal Studies 26, no.2 (Fall 2004): 339-345. https://doi.org/10.1163/157007404776111009.

Sun, Benjamin. "Assemblies of God Theological Education in Asia Pacific: A Reflection." Asian Journal of Pentecostal Studies 3, no.2 (2000): 227-251.

https://www.academia.edu/64155583/Benjamin_Sun_Assemblies_of_God_Theological_Ed ucation_in_Asia_Pacific_A_Reflection_pp_227_251. 
Tomaro, Queenie Pearl Villalon. "ICT integration in the educational system of Philippines." Journal of Governance and Public Policy 5, no.3 (2018): 259-282. https://doi.org/10.18196/jgpp.5399.

Van Wart, Montgomery, Anna Ni, Pamela Medina, Jesus Canelon, Melika Kordrostami, Jing Zhang, and Yu Liu. "Integrating students' perspectives about online learning: a hierarchy of factors." International Journal of Educational Technology in Higher Education 17, no.53 (2020). https://doi.org/10.1186/s41239-020-00229-8.

Warren, Rick. The Purpose Driven Church. Manila: OMF Literature Inc., 1998.

Wishart, Jocelyn. "Internet Safety in Emerging Educational Contexts." Computers $\&$ Education 43, iss.1-2 (2004): 193-204. https://doi.org/10.1016/j.compedu.2003.12.013. 